\title{
The 'Qualis' system (Brazil) in an interdisciplinary-ecological context
}

\author{
A. Begossi $i^{a, b, c *}$ \\ aPrograma de Capacitação de Pescadores Artesanais para o Manejo da Pesca - CAPESCA, Núcleo de Estudos da \\ Alimentação - NEPA, Universidade Estadual de Campinas - UNICAMP, Av. Albert Einstein, 291, \\ CEP 13083-852, Campinas, SP, Brazil

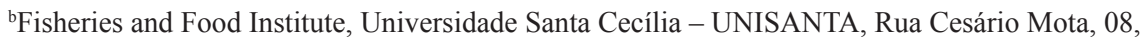 \\ CEP 11045-040, Santos, SP, Brazil \\ 'Programa Pos-graduação em Sustentabilidade de Sistemas Costeiros e Marinhos - ECOMAR, \\ Universidade Santa Cecília - UNISANTA, Rua Cesário Mota, 08, CEP 11045-040, Santos, SP, Brazil \\ *e-mail: alpinab@uol.com.br
}

\begin{abstract}
'Qualis' is the system used by CAPES (Coordenação de Pessoal de Nivel Superior), the agency that manages Graduate Teaching and Research Production in Brazil, in order to evaluate 'the quality of the intellectual production of the Graduate Programs'(CAPES, 2016). In fact, 'Qualis' support the evaluation system in Brazil that allocates funding to research and to graduate teaching in Brazil.

The 'Qualis system', instead of using the current Impact factor of periodicals (Research Gate, 2015; SciJournal, 2015; Scimago Journal, 2015 (lets call them IF) and based on obscure criteria, manipulates the system by creating the levels of impact factors of periodicals as upper (A1), followed by A2, B1, B2, B3, $\mathrm{B} 4, \mathrm{~B} 5$ and $\mathrm{C}=$ zero [1]. There are areas in which the
\end{abstract}

periodical does not exist (Table 1). Are 'Qualis' levels representative of IF? No. Table 1 shows some examples in areas such as Biodiversity, Environmental Sciences and Interdisciplinary (April 10 $0^{\text {th }}, 2015$ ). For example, if you are an ecologist, and you publish in Ecosystems, Ecology and Society, Current Anthropology and Bulletin of Marine Science, you get a zero in production. Observe that the IF of these are, respectively (July 30, 2015), $3.53 ; 2.67 ; 2.93 ; 0.87$. Ironically, periodicals with an IF of 0.87 , such as the Anais da Academia de Ciências, are considered in the upper strata (Qualis A2). The illustrative Table speaks for itself.

The perverse part of 'Qualis' is the punishing of scientists that, in spite of publishing in high international

Table 1. Impact Factors (July 30, 2015) ${ }^{1}$ and CAPES Qualis Impact Factors (Brazil) (from the highest A1 to B1, B2, B3, B4, B5 and lowest C; April $10^{\text {th }}$ 2015).

\begin{tabular}{|c|c|c|c|c|}
\hline Periodical & $\begin{array}{l}\text { Impact } \\
\text { Factor }^{1}\end{array}$ & $\begin{array}{c}\text { Biodiversity } \\
\text { ("Biodiversidade") }\end{array}$ & $\begin{array}{c}\text { Environmental } \\
\text { Science } \\
\text { ("Ciências } \\
\text { Ambientais") }\end{array}$ & $\begin{array}{l}\text { Interdisciplinary } \\
\text { ("Interdisciplinar") }\end{array}$ \\
\hline Ecological Applications & 4.13 & A1 & A1 & A1 \\
\hline Ecosystems & 3.53 & A1 & 0 & A1 \\
\hline Current Opinion in Environmental Sustainability & 3.49 & A2 & A2 & A2 \\
\hline Current Anthropology & 2.93 & B1 & 0 & A1 \\
\hline Ecology and Society & 2.67 & $\mathrm{~A} 2$ & 0 & 0 \\
\hline Hydrobiologia & 2.21 & A2 & $\mathrm{A} 2$ & $\mathrm{~A} 2$ \\
\hline Journal of Ethnobiology and Ethnomedicine & 2.00 & B1 & B3 & A2 \\
\hline Human Ecology [ Springer, 0300-7839] & 1.63 & B1 & A2 & A1 \\
\hline Environmental Biology of Fishes & 1.36 & $\mathrm{~A} 2$ & B1 & B1 \\
\hline Bulletin of Marine Science & 0.87 & B1 & 0 & B1 \\
\hline Anais da Academia Brasileira de Ciências & 0.87 & A2 & A2 & A1 \\
\hline Economic Botany ${ }^{2}$ & 0.77 & B1 & B1 & B1 \\
\hline Acta Botanica Brasilica (print) & 0.55 & B2 & $\mathrm{A} 2$ & $\mathrm{~A} 2$ \\
\hline Boletim do Instituto de Pesca & 0.34 & $\mathrm{~B} 2$ & B2 & $\mathrm{B} 2$ \\
\hline Interciência $^{3}$ & 0.25 & B2 & B1 & B1 \\
\hline
\end{tabular}

Zero (0) means that the periodical is not classified in the system (does not exist for the research area of Qualis). Illustrative data for some periodicals of the area of Biodiversity, Environmental Sciences and Interdisciplinary. ${ }^{1}$ Research Gate (2015); SCIJOURNAL (2015); SJR (2015). ${ }^{2}$ Economic Botany is A2 in Agricultural Science. ${ }^{3}$ Interciencia is A1 for Teaching; Regional and Urban Planning and Demography; A2 for Geography. 
impact periodicals, will get a low Qualis impact; worse than that, young Brazilian researchers are following wrong tracks: instead of deciding where to publish, based on their research themes, journal objectives and IF, they end up following the 'Qualis' system through the easiest path. For example, by publishing in the Anais da Academia de Ciências $(0.87 \text { IF })^{2}$ they get an $\mathrm{A}$ in all three areas (Biodiversity, Ciências Ambientais and Interdisciplinary). Maybe that could help explaining the relatively low international ranking of the Brazilian Universities. Unfortunately, 'Qualis' helps science in Brazil to run backwards.

\section{References}

COORDENACAO DE PESSOAL DE NIVEL SUPERIOR CAPES [online], 2016 [viewed 10 April 2015]. Available from: http://www.capes.gov.br/avaliacao/instrumentos-de-apoio/ classificacao-da-producao-intelectual

RESEARCH GATE [online], 2015. [viewed 10 April 2015]. Available from: https://www.researchgate.net/topic/journal_impact_factor SCIJOURNAL [online], 2015. [viewed 10 April 2015]. Available from: http://www.scijournal.org

SCIMAGO JOURNAL \& COUNTRY RANK - SJR [online], 2015. [viewed 10 April 2015]. Available from: http://www. scimagojr.com 